\title{
LETTER
}

\section{The influence of anti-cyclic citrullinated peptide on anticentromere antibody-positive rheumatoid arthritis patients: authors' response}

\author{
Panayiotis G Vlachoyiannopoulos* and Vasiliki-Kalliopi Bournia \\ See related research by Bournia et al., http://arthritis-research.com/content/12/2/R47, and related letter by Jearn and Kim, \\ http://arthritis-research.com/content/12/5/406
}

It was with great interest that we read the results presented by Professors La-He Jearn and Think-You Kim regarding the influence of anti-cyclic citrullinated peptide (CCP) on anticentromere antibody (ACA)positive patients suffering from rheumatoid arthritis (RA) [1]. Their findings explore the effect of ACA positivity in a patient group different from the cohort of primary Sjögren syndrome (SS) patients we chose to study [2]. Due to the different study population and the retrospective nature of our work, our data do not include measurement of anti-CCP antibodies. Anti-CCP antibodies provide a specific tool for the diagnosis of RA that seems to correlate with disease severity and early erosive disease. The method has a 70\% sensitivity for RA [3], which is consistent with the $70.6 \%$ positivity of anti-CCP reported by Jearn and Kim among their ACA-positive RA group. A striking point in the results presented by the two colleagues is the high prevalence (21\%) of RA among ACA-positive patients, which is not in line with previous publications that have reported a prevalence of 5 to $6 \%$ [4]. In a general population of RA patients with variable antibody background, interstitial lung disease and Raynaud's phenomenon have a reported prevalence in the range of 7.7 to $10 \%$ [5]. Jearn and Kim found 4 (11.8\%) patients with interstitial lung disease and 1 (10\%) patient with Raynaud's phenomenon out of 34 ACA-positive RA patients. Despite the fact that the numbers are small and do not allow for safe conclusions, both results are well in the range reported in the literature for unselected RA patients and unrelated to the anti-CCP positivity. This could, in a sense, indicate that the presence of ACA or anti-CCP antibodies in RA does not affect the clinical features in question. We believe that an extended presentation of the results found by Jearn and Kim would be very interesting and more than welcome. We also think that evaluation of our ACA-positive SS patients for anti-CCP reactivity should be interesting.

\section{Abbreviations \\ ACA, anticentromere antibody; CCP, cyclic citrullinated peptide; RA, rheumatoid arthritis; SS, Sjögren's syndrome.}

\section{Competing interests}

The authors declare that they have no competing interests.

\section{Published: 29 October 2010}

\section{References}

1. Jearn L-H, Kim T-Y: The influence of anti-cyclic citrullinated peptide on anticentromere antibody-positive rheumatoid arthritis patients. Arthritis Res Ther 2010, 12:406.

2. Bournia VK, Diamanti KD, Vlachoyiannopoulos PG, Moutsopoulos HM: Anticentromere antibody positive Sjögren's syndrome: a retrospective descriptive analysis. Arthritis Res Ther 2010, 12:R47.

3. van Venrooij WJ, van Beers JJ, Pruijn GJ: Anti-CCP antibody, a marker for the early detection of rheumatoid arthritis. Ann N Y Acad Sci 2008, 1143:268-285.

4. Vlachoyiannopoulos PG, Drosos AA, Wiik A, Moutsopoulos HM: Patients with anticentromere antibodies, clinical features, diagnoses and evolution. $\mathrm{Br} J$ Rheumatol 1993, 32:297-301.

5. Bongartz T, Nannini C, Medina-Velasquez YF, Achenbach SJ, Crowson CS, Ryu $J H$, Vassallo R, Gabriel SE, Matteson EL: Incidence and mortality of interstitial lung disease in rheumatoid arthritis: A population-based study. Arthritis Rheum 2010, 62:1583-1591.

\section{doi:10.1186/ar3154}

Cite this article as: Vlachotiannopoulos PG, Bournia V-K: The influence of anti-cyclic citrullinated peptide on anticentromere antibody-positive rheumatoid arthritis patients: authors' response. Arthritis Research \& Therapy 2010, 12:407.

\footnotetext{
*Correspondence: pvlah@med.uoa.gr

Department of Pathophysiology, Medical School, National University of Athens, 75 Mikras Asias Street, 11528 Athens, Greece
} 